\title{
Changes in Colour, Strength and Chemical Properties of Oil Heat Treated 18-Years Old Planted Acacia mangium
}

\author{
Razak Wahab ${ }^{1}$, Ros Syazmini M. Ghani ${ }^{2}$, Hashim W. Samsi ${ }^{3} \&$ Mohd Sukhairi M. Rasat $^{2}$ \\ ${ }^{1}$ University College of Technology Sarawak, 96000 Sibu, Sarawak, Malaysia \\ ${ }^{2}$ Universiti Malaysia Kelantan (UMK), Campus Jeli, 17600 Kelantan, Malaysia \\ ${ }^{3}$ Forest Research Institute Malaysia, 52109 Kepong, Selangor, Malaysia \\ Correspondence: Razak Wahab, University College of Technology Sarawak, 96000 Sibu, Sarawak, Malaysia. \\ E-mail: drrazakw5181@ucts.edu.my
}

Received: March 29, 2017

Accepted: April 19, 2017

Online Published: May 6, 2017

doi:10.5539/ijb.v9n3p12

URL: https://doi.org/10.5539/ijb.v9n3p12

\begin{abstract}
This study was carried to investigate changes in the oil heat treated 18-years old of planted Acacia mangium. Harvested trees segregated into bottom, middle and top portions containing heartwood and sapwood were oil heat treated in stainless tank with palm crude oil as heating medium at temperatures of $180^{\circ} \mathrm{C}, 200^{\circ} \mathrm{C}$ and $220^{\circ} \mathrm{C}$ for 30, 60 and 90 minutes respectively. The evaluation of the changes in the wood were performed by standards using a Minolta Chroma Meter, TAPPI Standard T204 om-88, TAPPI Standard T203 cm-99, TAPPI Standard T222 cm-02, and BS EN 310:1993 static bending tests. The relationship between the changes in the colour, mechanical and chemical composition, were made using correlation analysis. The result showed oil-heat treatment reduced the lightness of the wood and darkened the both parts of the wood. The strength of the wood reduced slightly after the oil-heat treatment. In the chemical compositions, the percentages of the holocellulose, $\alpha$-cellulose, hemicellulose and extractive contents decrease with the increase in treatment duration and temperature. The oil heat treatment process at $200^{\circ} \mathrm{C}$ for duration 60 minutes is recommended for acacia mangium wood as it improved the colour of Acacia mangium and standardized the colour of sapwood and heartwood. The loss in strength at this temperature and duration is acceptable as the treated wood only loss up to $15 \%$ strength in MOR and $10.7 \%$ in MOE.
\end{abstract}

Keywords: Acacia mangium, oil heat treatment, colour features, strength, chemical changes.

\section{Introduction}

Acacia mangium a fast-grown timber species is an important for large scale forest plantation in Malaysia. This fast-growing species has some disadvantages such as it has high proportion of juvenile wood, poorly developed heartwood and fast rate of growth that resulted in wide growth rings which eventually will lower the density of wood thus dropped the dimensional stability and readily attacked by biological deterioration agent (Tuong $\&$ Li, 2010). In order to enhance the durability against bio-deterioration the A. mangium wood need to be chemically treated with preservatives. Increased in environmental awareness and effective policies that support the use of renewable resources and environmental-friendly chemicals had resulted in high interest for 'non-biocidal' substances. Heat treatment is one of the wood modification processes that are environmental-friendly as it does not use chemicals (Razak et al., 2012; Izyan et al., 2010). The $A$. mangium an exotic timber species to Malaysia was chosen for this study.

The study investigated the effect of heat treatment on properties of wood before and after the treatment. The objectives of the present study were to investigate effects of the treatment on; i). Colour changes in the sap- and heartwood of the wood, ii). Main chemical changes, and iii). Strength changes of the wood before and after treatment. The result of this study benefits immensely regarding improving technology in treated wood to produce good quality $A$. mangium products 


\section{Method}

\subsection{Samples Preparation and Treatment}

a. Tree Harvesting

Acacia mangium trees with long straight bole, decay free and with minimum branches were harvested from Jeli plantation forest, in Kelantan. The trees chosen had an average of $30 \mathrm{~cm}$ diameter at breast height (DBH) and height of at least $12 \mathrm{~m}$ in height and about 18 -years old. The wood segregated into three portions which are the bottom, middle and the top. Then they were into samples of $30 \mathrm{~cm} \times 10 \mathrm{~cm} \times 2.5 \mathrm{~cm}$ with both portion of sapwood and heartwood on every wood piece. The wood pieces were then condition to $12 \%$ moisture content in a conditioning chamber with a temperature of $20 \pm 5^{\circ} \mathrm{C}$ and relative humidity (RH) of $65 \pm 5 \%$ for two weeks.

\section{b. Oil Heat Treatment}

Three (3) treatment temperatures of 180,200 and $220^{\circ} \mathrm{C}$ and treatment durations of 30,60 and 90 minutes were used in the process. Palm oil was used as a heating medium as it is organic in nature. A stainless steel tank was used to treat the wood. The tank was three-quarter filled with oil. The wood samples were placed into the tank when the oil reached a temperature of $80^{\circ} \mathrm{C}$. The temperatures checked every 10 minutes. After each treatment period ends, the wood removed from the tank while the oil is still hot. The samples were then wiped with a clean cloth to avoid excessive oil from entering the tissue of the wood and then cooled down. The wood was then conditioned in a conditioning chamber set at $20 \pm 2{ }^{\circ} \mathrm{C}$ and $\mathrm{RH}$ of $65 \pm 5 \%$.

\subsection{Samples Testing \\ a. Colour Analysis}

The colour measurement performed on the acacia wood at 180,200 and $220^{\circ} \mathrm{C}$ after oil heat treated at durations of 30,60 and 90 minutes. The wood surfaces were cleaned and marked for consistency at the cross-section surfaces of sapwood and heartwood. The changes in colour of the wood surface due to oil heat treatment were recorded using a Minolta Chroma Meter CR-10. Readings were taken before and after the oil heat treatment process. The value of $\Delta \mathrm{L}^{*}, \Delta \mathrm{C}^{*}$ and $\Delta \mathrm{E}^{*}$ were used to calculate the colour change before and after the treatment. $\Delta \mathrm{L}^{*}$ measured for the change in lightness. The value of $\Delta \mathrm{C}^{*}$ is chroma differences. While, $\Delta \mathrm{E}^{*}$ indicates total colour differences value.

b. Strength Properties

Samples conditioned to $12 \%$ moisture contrent (MC) in a conditioning chamber set at temperature of $205^{\circ} \mathrm{C}$ and $65 \pm 5 \% \mathrm{RH}$ for at two weeks before testing. The strength tests carried out was the bending strength tests by BS EN 310:1993 using a Testomeric machine number 0500-11213. The specimen size for bending test was $5 \mathrm{~cm} \times 29 \mathrm{~cm}$ with an effective span of $150 \mathrm{~mm}$ and force applied at the mid-span using a loading head. Samples loaded on the radial surface. The tests stopped when the samples started to break. The proportional limit and ultimate load and deflection recorded while the MOE and MOR value calculated automatically.

c. Chemical Analysis

Chemical composition in Acacia mangium before and after heat treatment was analyzed. The chemical components examined were the holocellulose, hemicellulose, $\alpha$-cellulose, Klason lignin and alcohol-toluene solubility for extractive. All the chemical analysis tests were conducted separately for heartwood and sapwood. The evaluation of chemical constituents of Acacia mangium carried out according to TAPPI standards (TAPPI T204, TAPPI T203, TAPPI T222) and Razak et al., (2011).

Sample Preparation for Chemical Analysis: The wood first chipped for grinding purposes. Samples grounded into powder to pass BS 40-mesh sieve and retained on BS 60-mesh sieve. They were air-dried for three (3) days.

Determination of Holocellulose, $\alpha$-Cellulose and Hemicellulose, Klason Lignin and Alcohol-toluene Solubility: TAPPI Standard T204 om-88 (1997) and methods outlined by Razak et al., (2011) were used in determining the holocellulose, $\alpha$-cellulose and hemicellulose, klason lignin contents and alcohol-toluene solubility before and after undergoing the oil heat treated.

\section{Results and Discussion}

\section{a. Colour Properties}

After completing oil-heat treatment process, oil remaining on the wood surface was absorbed by wood quickly while cooling down causing dry wood surface appeared instantaneously (Rapp \& Sailer, 2001). The oil-heat treatment had caused the surface colour of wood to darken. This is a favourable outcome because it achieved the first objective for this research which is to enhance the colour of wood surface especially in sapwood and to homogenize the colour between heartwood and sapwood. The consistency of colour varies due to variation 
especially in density and type of wood used (Aydemir et al., 2010). Tables 1-6 showed the results of the colour changes before and after undergoing the oil heat treated treatment.

Table 1. Colour Values of Heartwood (Bottom portion)

\begin{tabular}{ccccccccccc}
\hline \multicolumn{1}{c}{ Treatment } & \multicolumn{10}{c}{ Sapwood } \\
\hline Temp. $\left({ }^{\circ} \mathrm{C}\right)$ & Dur. $(\min )$ & $\mathrm{L}^{*}$ & $\mathrm{a}^{*}$ & $\mathrm{~b}^{*}$ & $\mathrm{~L}_{\mathrm{t}}{ }^{*}$ & $\mathrm{a}_{\mathrm{t}}{ }^{*}$ & $\mathrm{~b}_{\mathrm{t}}{ }^{*}$ & $\Delta \mathrm{C}$ & $\Delta \mathrm{L}$ & $\Delta \mathrm{E}^{*}$ \\
\hline \multirow{2}{*}{180} & 30 & 26.2 & 10.0 & 14.2 & 24.9 & 10.7 & 7.9 & -4.1 & -1.3 & 6.5 \\
& 60 & 25.1 & 8.3 & 8.6 & 21.7 & 4.0 & 2.9 & -6.0 & -3.4 & 7.9 \\
& 90 & 28.2 & 11.9 & 13.6 & 23.6 & 7.9 & 7.0 & -7.6 & -4.6 & 9.1 \\
\hline \multirow{2}{*}{200} & 30 & 25.4 & 10.3 & 9.9 & 23.4 & 6.3 & 5.7 & -5.8 & -2.0 & 6.2 \\
& 60 & 28.3 & 10.4 & 11.1 & 23.7 & 5.3 & 5.5 & -7.6 & -4.7 & 9.2 \\
& 90 & 26.7 & 12.1 & 13.9 & 20.9 & 5.6 & 5.8 & -10.4 & -5.8 & 12.1 \\
\hline 220 & 30 & 22.3 & 9.2 & 7.9 & 19.7 & 2.5 & 2.5 & -8.6 & -2.6 & 9.0 \\
& 60 & 21.2 & 10.2 & 8.3 & 15.7 & 1.6 & 2.3 & -10.4 & -5.5 & 11.9 \\
& 90 & 40.4 & 10.0 & 15.7 & 19.7 & 7.1 & 6.0 & -11.8 & -6.8 & 13.6 \\
\hline
\end{tabular}

Table 2. Colour Values of Sapwood (Bottom portion)

\begin{tabular}{|c|c|c|c|c|c|c|c|c|c|c|}
\hline \multicolumn{2}{|c|}{ Treatment } & \multicolumn{9}{|c|}{ Sapwood } \\
\hline Temp. $\left({ }^{\circ} \mathrm{C}\right)$ & Dur. (min) & $\mathrm{L}^{*}$ & $a^{*}$ & $b^{*}$ & $\mathrm{~L}_{\mathrm{t}}^{*}$ & $a_{t}^{*}$ & $\mathrm{~b}_{\mathrm{t}}{ }^{*}$ & $\Delta \mathrm{C}$ & $\Delta \mathrm{L}$ & $\Delta \mathrm{E}^{*}$ \\
\hline \multirow[t]{3}{*}{180} & 30 & 40.4 & 10.0 & 15.7 & 19.7 & 7.1 & 6.0 & -9.3 & -20.7 & 23.0 \\
\hline & 60 & 48.6 & 12.3 & 22.7 & 25.5 & 10.5 & 8.0 & -12.6 & -23.0 & 27.4 \\
\hline & 90 & 51.9 & 15.0 & 26.2 & 26.5 & 11.5 & 10.8 & -14.4 & -25.4 & 29.9 \\
\hline \multirow[t]{3}{*}{200} & 30 & 52.0 & 16.0 & 28.3 & 29.7 & 13.1 & 14.1 & -13.3 & -22.3 & 26.6 \\
\hline & 60 & 44.2 & 13.6 & 21.9 & 20.5 & 6.0 & 3.7 & -17.5 & -23.7 & 30.9 \\
\hline & 90 & 46.5 & 12.0 & 21.3 & 20.6 & 4.0 & 3.0 & -18.9 & -25.9 & 32.7 \\
\hline \multirow[t]{3}{*}{220} & 30 & 44.8 & 12.6 & 20.6 & 21.9 & 6.2 & 4.9 & -16.3 & -22.9 & 28.5 \\
\hline & 60 & 40.4 & 13.4 & 18.2 & 15.6 & 1.6 & 2.0 & -20.0 & -24.8 & 31.9 \\
\hline & 90 & 48.8 & 11.8 & 24.9 & 21.8 & 5.2 & 4.7 & -21.2 & -27.0 & 34.4 \\
\hline
\end{tabular}

Table 3. Colour Values of Heartwood (Middle portion)

\begin{tabular}{cccrcrrrrrr}
\hline \multicolumn{1}{c}{ Treatment } & \multicolumn{10}{c}{ Heartwood } \\
\hline Temp. $\left({ }^{\circ} \mathrm{C}\right)$ & Dur. (min) & \multicolumn{1}{c}{$\mathrm{L}^{*}$} & \multicolumn{1}{c}{$\mathrm{a}^{*}$} & \multicolumn{1}{c}{$\mathrm{b}^{*}$} & \multicolumn{1}{c}{$\mathrm{L}_{\mathrm{t}}{ }^{*}$} & $\mathrm{a}_{\mathrm{t}}{ }^{*}$ & $\mathrm{~b}_{\mathrm{t}}{ }^{*}$ & \multicolumn{1}{l}{$\Delta \mathrm{C}$} & \multicolumn{1}{c}{$\Delta \mathrm{L}$} & $\Delta \mathrm{E}^{*}$ \\
\hline 180 & 30 & 35.6 & 10.2 & 12.8 & 31.5 & 7.6 & 7.8 & -5.5 & -4.1 & 7.5 \\
& 60 & 37.2 & 9.7 & 12.8 & 32.6 & 6.9 & 6.0 & -6.9 & -4.6 & 8.8 \\
& 90 & 28.8 & 10.3 & 13.3 & 21.9 & 5.9 & 7.4 & -7.4 & -6.9 & 10.2 \\
\hline 200 & 30 & 33.5 & 10.4 & 14.9 & 25.1 & 5.0 & 7.2 & -9.4 & -8.4 & 12.6 \\
& 60 & 28.4 & 10.9 & 14.1 & 19.6 & 3.2 & 4.6 & -12.2 & -8.8 & 15.1 \\
& 90 & 34.3 & 10.0 & 14.9 & 22.9 & 2.3 & 4.9 & -12.6 & -11.4 & 17.0 \\
\hline 220 & 30 & 36.5 & 9.0 & 12.4 & 22.4 & 3.0 & 3.7 & -10.5 & -13.6 & 16.4 \\
& 60 & 31.8 & 11.4 & 13.4 & 17.5 & 2.8 & 3.0 & -13.5 & -14.3 & 19.7 \\
& 90 & 40.0 & 9.8 & 14.1 & 23.2 & 1.9 & 2.1 & -14.3 & -16.8 & 22.1 \\
\hline
\end{tabular}

Table 4. Colour Values of Sapwood (Middle portion)

\begin{tabular}{|c|c|c|c|c|c|c|c|c|c|c|}
\hline \multicolumn{2}{|c|}{ Treatment } & \multicolumn{9}{|c|}{ Sapwood } \\
\hline Temp. $\left({ }^{\circ} \mathrm{C}\right)$ & Dur. (min) & $\mathrm{L}^{*}$ & $a^{*}$ & $\mathrm{~b}^{*}$ & $\mathrm{~L}_{\mathrm{t}}^{*}$ & $\mathrm{a}_{\mathrm{t}}{ }^{*}$ & $b_{t}^{*}$ & $\Delta \mathrm{C}$ & $\Delta \mathrm{L}$ & $\Delta \mathrm{E}^{*}$ \\
\hline \multirow[t]{3}{*}{180} & 30 & 42.3 & 12.1 & 17.4 & 26.7 & 14.3 & 15.3 & -7.0 & -15.6 & 14.6 \\
\hline & 60 & 43.8 & 12.0 & 18.0 & 26.2 & 13.9 & 14.1 & -8.3 & -17.5 & 18.1 \\
\hline & 90 & 44.6 & 14.5 & 18.9 & 25.4 & 13.9 & 16.8 & -11.0 & -19.3 & 19.4 \\
\hline \multirow[t]{3}{*}{200} & 30 & 50.0 & 9.9 & 21.8 & 32.0 & 13.2 & 15.7 & -13.0 & -18.0 & 19.3 \\
\hline & 60 & 40.7 & 10.5 & 19.0 & 20.9 & 4.1 & 5.6 & -14.7 & -19.8 & 24.7 \\
\hline & 90 & 43.4 & 10.7 & 19.7 & 21.7 & 4.1 & 6.2 & -16.0 & -21.7 & 26.4 \\
\hline \multirow[t]{3}{*}{220} & 30 & 51.0 & 12.2 & 23.0 & 32.1 & 6.0 & 6.8 & -16.9 & -18.9 & 25.7 \\
\hline & 60 & 41.2 & 12.7 & 23.6 & 20.2 & 6.2 & 6.4 & -17.8 & -21.0 & 27.9 \\
\hline & 90 & 46.8 & 13.1 & 23.5 & 22.0 & 6.0 & 6.4 & -19.1 & -24.8 & 31.1 \\
\hline
\end{tabular}


Table 5. Colour Values of Heartwood (Top Portion)

\begin{tabular}{cccrrrrrrrr}
\hline \multicolumn{1}{c}{ Treatment } & \multicolumn{10}{c}{ Heartwood } \\
\hline Temp. $\left({ }^{\circ} \mathrm{C}\right)$ & Dur. $(\mathrm{min})$ & \multicolumn{1}{c}{$\mathrm{L}^{*}$} & \multicolumn{1}{c}{$\mathrm{a}^{*}$} & \multicolumn{1}{c}{$\mathrm{b}^{*}$} & $\mathrm{~L}_{\mathrm{t}}{ }^{*}$ & $\mathrm{a}_{\mathrm{t}}{ }^{*}$ & $\mathrm{~b}_{\mathrm{t}}{ }^{*}$ & \multicolumn{1}{c}{$\Delta \mathrm{C}$} & $\Delta \mathrm{L}$ & $\Delta \mathrm{E}^{*}$ \\
\hline \multirow{2}{*}{180} & 30 & 34.6 & 9.6 & 14.6 & 26.2 & 8.9 & 7.6 & -5.2 & -8.4 & 10.9 \\
& 60 & 35.3 & 9.8 & 15.3 & 24.0 & 8.8 & 9.0 & -6.7 & -11.3 & 13.1 \\
& 90 & 37.1 & 9.9 & 15.5 & 23.2 & 7.2 & 7.7 & -7.8 & -13.9 & 16.2 \\
\hline \multirow{2}{*}{200} & 30 & 35.5 & 10.6 & 13.8 & 24.8 & 3.7 & 3.6 & -12.1 & -10.8 & 16.3 \\
& 60 & 33.9 & 10.9 & 15.9 & 19.7 & 4.2 & 4.7 & -12.9 & -14.1 & 18.5 \\
& 90 & 33.2 & 11.7 & 15.2 & 16.3 & 3.0 & 3.9 & -14.3 & -16.9 & 22.1 \\
\hline \multirow{2}{*}{220} & 30 & 34.0 & 9.6 & 14.8 & 19.2 & 2.0 & 3.1 & -13.9 & -14.8 & 20.3 \\
& 60 & 37.1 & 9.9 & 16.8 & 19.2 & 2.6 & 2.7 & -15.9 & -17.9 & 24.0 \\
& 90 & 32.6 & 11.6 & 17.5 & 12.7 & 1.8 & 2.5 & -17.8 & -20.0 & 26.8 \\
\hline
\end{tabular}

Table 6. Colour Values of Sapwood (Top Portion)

\begin{tabular}{|c|c|c|c|c|c|c|c|c|c|c|}
\hline \multicolumn{2}{|c|}{ Treatment } & \multicolumn{9}{|c|}{ Sapwood } \\
\hline Temp. $\left({ }^{\circ} \mathrm{C}\right)$ & Dur. (min) & $\mathrm{L}^{*}$ & $a^{*}$ & $b^{*}$ & $\mathrm{~L}_{\mathrm{t}}^{*}$ & $a_{t}^{*}$ & $b_{t}^{*}$ & $\Delta \mathrm{C}$ & $\Delta \mathrm{L}$ & $\Delta \mathrm{E}^{*}$ \\
\hline \multirow[t]{3}{*}{180} & 30 & 54.3 & 14.4 & 26.0 & 37.8 & 11.7 & 19.9 & -6.7 & -16.5 & 16.6 \\
\hline & 60 & 41.2 & 12.6 & 20.1 & 22.9 & 8.2 & 12.9 & -8.3 & -18.3 & 20.1 \\
\hline & 90 & 43.3 & 9.9 & 16.2 & 24.2 & 8.8 & 7.5 & -9.8 & -19.2 & 21.2 \\
\hline \multirow[t]{3}{*}{200} & 30 & 47.1 & 11.8 & 19.7 & 27.7 & 9.2 & 9.6 & -9.7 & -19.4 & 21.3 \\
\hline & 60 & 51.3 & 11.7 & 22.5 & 30.6 & 8.8 & 8.1 & -13.5 & -20.7 & 25.4 \\
\hline & 90 & 40.7 & 14.0 & 19.3 & 19.3 & 4.1 & 4.7 & -15.7 & -21.3 & 27.7 \\
\hline \multirow[t]{3}{*}{220} & 30 & 46.1 & 11.9 & 19.6 & 23.2 & 7.2 & 6.9 & -13.0 & -22.9 & 26.6 \\
\hline & 60 & 53.0 & 11.4 & 20.2 & 29.0 & 4.9 & 3.5 & -17.2 & -24.0 & 30.0 \\
\hline & 90 & 49.7 & 12.2 & 21.2 & 24.7 & 4.1 & 3.8 & -18.8 & -25.0 & 31.5 \\
\hline
\end{tabular}

$\Delta \mathrm{C}=$ chroma changes, $\Delta \mathrm{L}^{*}=$ changes in lightness, $\Delta \mathrm{E}=$ total colour differences,

$\mathrm{L}^{*}=$ Brightness index (Higher reading indicates in lighter sample), $\mathrm{a}^{*}=$ "Chromaticness index" (Higher reading indicates reddish sample), $\mathrm{b}^{*}=$ "Chromaticness index" (Higher reading indicates yellowish sample),

$L^{*}, a^{*}$ and $b^{*}$ refer to sample after oil-heat treatment, $L^{*}, a^{*}{ }_{s}$ and $b^{*}$ refer to sample before heat treatment.

\section{Change in Lightness $\left(\Delta \mathrm{L}^{*}\right)$}

The changes in lightness $\left(\Delta \mathrm{L}^{*}\right)$ for heartwood from bottom to top portions occurred between -1.3 to -20.0 (Tables 1, 3 and 5). The negative value indicates the decreases in lightness after oil-heat treatment (Mononen et al., 2002; Feher et al., 2014). This resulting from decrement in certain chemical component especially hemicelluloses and lignin (Bekhta \& Niemz, 2003; Huang et al., 2012; Razak et al., 2012). The values of $\Delta L^{*}$ decreased with increased in duration and temperature where the wood surface darkened after treatment, and it is clearly visible to naked eyes. Izyan et al. (2010) supports this result, Cao et al. (2012), Razak et al. (2011) and Guller (2012) in their respective studies.

The heartwood treated for 30 minutes has the smallest change value of $\Delta \mathrm{L}^{*}$. The changes increase for treatment duration at 60 and 90 minutes. The values are low at the bottom portion of the acacia wood which was $-1.2,-1.1$ and -1.3 for each treatment temperature. The middle portion also showed small differences when treated at 30 and 60 minutes. The top part showed steadily decreased in a change in lightness for each treatment duration. The values of lightness change decrease with increases in temp. The value of $\Delta \mathrm{L}^{*}$ more observable when the temperature is above $180^{\circ} \mathrm{C}$. The value of $\Delta \mathrm{L}^{*}$ decreased with increasing in wood portion. For the bottom portion of the heartwood, the value of $\Delta \mathrm{L}^{*}$ range from -1.3 to -6.8 , middle from -4.1 to -16.8 and top -8.4 to -20.0 . This shows the wood height portion does not significantly affect the change in lightness.

The values of $\Delta \mathrm{L}^{*}$ for sapwood were between -14.3 to -27.0. The value of $\Delta \mathrm{L}^{*}$ for sapwood was much lower than heartwood (Tables 2, $4 \& 6$ ). Consequently, through oil-heat treatment, the colour of sapwood was slightly darkened compared to the colour of heartwood. The wood types (sapwood and heartwood) significantly affecting the $\Delta \mathrm{L}^{*}$ and proven by the correlation analysis shown in Table 10 . The darker colour produced caused by the polyphenols compounds that related to the dark colour of heartwood that moves to the sapwood and changed the colour of sapwood from light to dark (Razak et al., 2012). Moreover, the darker colour of the wood surface in sapwood is caused by coloured staining in outer shell as a result of the accumulation of sugar near the surface during capillary phase (Aydemir et al., 2010). 
The values of $\Delta \mathrm{L}^{*}$ decreased with increased in the duration of treatment. Compared to heartwood, there were only small and steady differences in reduction of lightness with increasing duration. The lowest decreased in lightness occurred at a top part of the tree for 60 and 90 minutes with - 0.6 differences. The comparison between temperature and $\Delta \mathrm{L}^{*}$ also shows a steady decrease in lightness, but there is a further darkening of wood that treated over $200^{\circ} \mathrm{C}$. This result supported by a study conducted by Bekhta and Niemz, (2003) and Razak et al., (2012). The colour of sapwood and heartwood tended to be uniform when the temperature is higher than $200^{\circ} \mathrm{C}$. It was observed that the wood of middle and the top portions after reaching $200^{\circ} \mathrm{C}$ experiences decreases of $\Delta \mathrm{L}^{*}$ up to -3.8 . The considerably decreased in lightness changes increases temperature rather than extending the duration of treatment. This is supported by Aydemir et al., 2012 in their study on the effect of thermal treatment on the colour of six different wood species. The changes in lightness varies between the tree heights. The bottom portion has values between -20.7 to -27.0 , middle -15.6 to -24.8 and top -16.5 to -25.0 .

Change of Chroma Colour $(\Delta \mathbf{C})$ : The values of changes of chroma $(\Delta \mathrm{C})$ for the heartwood were -4.1 to -17.8 . The value decreases with increasing in treatment duration. At the bottom portion, the declined were constant but not more than -2.0. The middle and top portion of the tree experiences slight decreases in $\Delta \mathrm{C}$ with duration increment. The value also decreases with increasing in temperature treatment. The major decreased occurred when the treatment started at $180^{\circ} \mathrm{C}$. This is due to the values of $\mathrm{a}^{*}$ and $\mathrm{b}^{*}$ affected by temperature below $160^{\circ} \mathrm{C}$. The wood portion in height does not cause variation in the value of $\Delta \mathrm{C}$. The changes in hue indicate that there are changes in chromophores. It suggested that some molecules with chromophoric function loss and some increase in content and polymerization take place during the heat treatment (Sundqvist, 2004).

The reddish colour appearances caused by secondary formation condensation or degradation products of quinine, and quinonemethide types where the by-products formed absorbs the complementary light of reddish colour and contribute to the redness of wood (Kacik et al., 2015). It is also related to the greater amounts of Brauns' lignin and proanthocyanidins and extractives content of wood (Feher et al., 2014). The yellowish colour was caused by low molecular weight phenolic substances and is tightly connected to the chemical component of cell wall which are cellulose, hemicelluloses and lignin (Chen et al., 2012; Feher et al., 2014). Whereas, the blue colour is a sign of stain where it is due to the photo-oxidation of lignin and extractives with the production of coloured quinine component (Izyan et al., 2010).

The values of $\Delta \mathrm{C}$ were between -9.3 to -21.2 for sapwood. The $\Delta \mathrm{C}$ in sapwood is higher than the heartwood since it was originally lighter in colour and eventually during the oil-heat treatment, the colour changed into dark brown (Cao et al., 2012). The difference in wood type is significantly affecting the $\Delta \mathrm{C}$ according to correlation analysis (Table 10). The values increase with increasing duration treatment. At the bottom and the top portion, the decreases was higher when wood treated for 60 and $90 \mathrm{~min}$. where the declined are almost identical. Whereas, in the middle portion experiences only slight differences between each length of treatments. The values also decreased with increased in temperature. A significant change in colour obtained for sapwood even when it was treated for a short period. The wood started to decreases at the beginning of treatment, and this trend continues at $200^{\circ} \mathrm{C}$ where the decreases in $\Delta \mathrm{C}$ were more evident. The same results were obtained for heartwood (Cao et al., 2012) where the values were between 170 to $200^{\circ} \mathrm{C}$

In comparison, treatment temperatures have more influence on $\Delta \mathrm{C}$ than duration for both sapwood and heartwood. It may be suggested that increases in temperature can reduce the length of heat treatment to obtain desired wood colour. Besides, the slow colour formation produce at a lower temperature can be balanced with prolonging the treatment duration (Sundqvist, 2004).

Total Colour Differences $(\Delta \mathrm{E})$ : The total colour differences $(\Delta \mathrm{E})$ indicates the degree of overall chemical modification where the degradation products are hemicelluloses, lignin and extractives compounds participating in the colour formation of the wood (Sundqvist, 2004; Chen et al., 2012). The values of $\Delta \mathrm{E}$ increases with increases in treatment duration. At the bottom and middle portions, only slight differences in the value of $\Delta \mathrm{E}$ for 30,60 and 90 minutes at $180^{\circ} \mathrm{C}$. The values of $\Delta \mathrm{E}$ increases with the increased temperature of oil-heat treatment. The increased in $\Delta \mathrm{E}$ were more noticeable with increasing temperature for the middle and top portions.

The treatment temperature and duration influenced the value of $\Delta \mathrm{E}$. Temperature is significantly affecting the $\Delta \mathrm{E}$ more than the treatment duration. The rate of change increases with increases in temperature under the same duration, but decreases when the duration extends even at a maintained temperature (Cao et al., 2012). This explained by the small differences in colour of wood treated at 30,60 and 90 minutes at the same temperature. The value of $\Delta \mathrm{E}$ increases with increasing temperature as observable in the middle and the top portions when treated at $200^{\circ} \mathrm{C}$ and $220^{\circ} \mathrm{C}$ rather than $180^{\circ} \mathrm{C}$ where the value of $\Delta \mathrm{E}$ is larger. The heartwood has the $\Delta \mathrm{E}$ around 6.5 to 26.8 which were lower than sapwood. This due to the original colour of sapwood is lighter than heartwood. Like $\Delta \mathrm{L}^{*}$ 
and $\Delta \mathrm{C}$, the wood type (sapwood and heartwood) significantly affecting the $\Delta \mathrm{E}$. The oil-heat treatment turned the sapwood colour more noticeable than the heartwood. No significance obtained on the $\Delta \mathrm{E}$ between the tree portions sampling heights of the bottom, middle and top for both heartwood and sapwood are observed.

The $\Delta \mathrm{E}$ caused by the formation of secondary condensation products and degradation products. The degradation products include the reactive compounds from cleavage of $\alpha$ - and $\beta$-aryl ether bonds in lignin and hemicelluloses (Chen et al., 2012). It also correlated with holocellulose content since it is easily degraded during heat treatment process (Huang et al., 2012). Table 10 showed the correlation between the total colour differences with extractive, holocellulose, cellulose and hemicelluloses contents. Temperature significantly affected all the wood properties except for the change in lightness.

Duration of treatment is an important variable that affected the oil-heat treated wood beside temperature but was less significantly affected the colour properties after treatment where it was only significantly affected the chroma changes. It may lead due to shorter duration of treatment which insufficient to modify the wood properties. The type of wood which is sapwood and heartwood shows significant differences in all colour properties. Colour significantly affected by the type of wood because Acacia mangium have a different colour of sapwood and heartwood and through oil-heat treatment, the colour of sapwood is slightly darkened to match the colour of heartwood thus it affecting the colour properties.

\section{b. Strength Properties}

The oil-heat treatment incurred some reduction in the strength properties of the acacia wood in static bending tests in both the Modulus of Rupture (MOR) and Modulus of Elasticity (MOE). This is due to the degradation of chemical contents especially cellulose which responsible for wood strength due to its long parallel and straight molecules packed together (Sundqvist, 2004). By manipulating the temperature of treatment and treatment duration, the reduction in wood strength can be minimized or avoided.

\section{Modulus of Rupture}

Table 7 shows the MOR and MOE of oil-heat treated Acacia mangium wood. The MOR of control samples of taken at the bottom, middle and top portions of this study is $108.2 \mathrm{~N} / \mathrm{mm}^{2}, 105.4 \mathrm{~N} / \mathrm{mm}^{2}$ and $105.0 \mathrm{~N} / \mathrm{mm}^{2}$ at $12 \%$ $\mathrm{MC}$ respectively. The increases in duration of treatment decrease the MOR of the wood. In the bottom and middle portions of the wood, increases in duration not affecting the MOR greatly where the highest percentage change is only $6.5 \%$ loss when wood is treated at 60 and 90 minutes. Whereas at the top part of the tree, the decreased in MOR is higher with increased in treatment duration with at least $4 \%$ of MOR decreased. However, similar to bottom and middle part decreased in MOR is significant when wood is treated at 60 minutes. Kubojima et al. (2000) studied on the bending strength of Sitka spruce also observed the similar outcome. Nonetheless, even though duration affected the properties of wood, it is less significant.

At the bottom portion of the tree, MOR loss $5 \%$ when wood is treated at $180^{\circ} \mathrm{C}$ and $200^{\circ} \mathrm{C}$. While in middle and top parts, MOR loss doubled at every increased in treatment temperature. Increased in temperature significantly affected the MOR of treated wood (Table 7). This is supported by Kubojima et al. (2000), Poncsak et al. (2006), Korkut and Hiziroglu (2009), Sahin (2010) and Kesik et al., (2014) where they suggested further heating will decrease the MOR significantly.

At the bottom and middle height of wood, the values of decreased in MOR were almost the same with the highest percent change of $18.9 \%$ and $16.6 \%$ respectively. While at the top part, the highest percentage change occurred at $220^{\circ} \mathrm{C}$ for 90 minutes where $24.9 \%$ of MOR reduction. This is in agreement with Sundqvist, (2004), where strength loss in thermally treated wood was between 0 to $30 \%$ depending on the process, and at $220^{\circ} \mathrm{C}$, the strength loss is rapidly decreased up to $30 \%$, the MOR decreased for about $24 \%$ with heat treatment. It is presumed that changes in mechanical properties are related to the formation and accumulation of organic acid in wood which emits to the surrounding atmosphere during the process (Sundqvist, 2004).

The heat treatment had caused a reduction in strength to the treated samples due to thermal degradation and loss of substances due to depolymerization reaction of wood polymer especially changes in hemicelluloses and cellulose contents (Kotilainen, 2000; Poncsak et al., 2006). Moreover, viscosity and plasticity of wood are believed to affect the wood rupture in treated wood (Kubojima et al., 2000). In this study, the reduction of MOR occurred because the heat treatment was done over $180^{\circ} \mathrm{C}$. The effect on dropped in strength and wood brittleness were believed to start when the temperature of treatment over $175^{\circ} \mathrm{C}$ (Yildiz et al., 2006). However, a study by Cao et al. (2012) suggests that strength properties can be enhanced by lower temperature and shorter duration of treatment. 
Table 7. Modulus of Rupture (MOR) and Modulus of Elasticity (MOE)

\begin{tabular}{cccccccc}
\hline \multicolumn{2}{c}{ Treatment } & \multicolumn{2}{c}{ Bottom } & \multicolumn{2}{c}{ Middle } & \multicolumn{2}{c}{ Top } \\
\hline $\begin{array}{c}\text { Temp. } \\
\left({ }^{\circ} \mathrm{C}\right)\end{array}$ & $\begin{array}{c}\text { Dur. } \\
(\mathrm{min})\end{array}$ & $\begin{array}{c}\text { MOR } \\
\left(\mathrm{N} / \mathrm{mm}^{2}\right)\end{array}$ & $\begin{array}{c}\text { MOE } \\
\left(\mathrm{N} / \mathrm{mm}^{2}\right)\end{array}$ & $\begin{array}{c}\text { MOR } \\
\left(\mathrm{N} / \mathrm{mm}^{2}\right)\end{array}$ & $\begin{array}{c}\text { MOE } \\
\left(\mathrm{N} / \mathrm{mm}^{2}\right)\end{array}$ & $\begin{array}{c}\text { MOR } \\
\left(\mathrm{N} / \mathrm{mm}^{2}\right)\end{array}$ & $\begin{array}{c}\text { MOE } \\
\left(\mathrm{N} / \mathrm{mm}^{2}\right)\end{array}$ \\
\hline Control & 0 & 108.2 & 6876.7 & 105.4 & 6988.6 & 105.0 & 7111.8 \\
180 & 30 & 102.8 & 6665.9 & 102.6 & 6835.5 & 101.0 & 6966.7 \\
& 60 & 101.1 & 6500.7 & 100.7 & 6795.9 & 97.0 & 6897.6 \\
& 90 & 98.4 & 6332.3 & 98.5 & 6662.4 & 91.5 & 6866.7 \\
200 & 30 & 98.4 & 6296.7 & 98.3 & 6261.7 & 99.2 & 6660.9 \\
& 60 & 92.0 & 6164.9 & 95.3 & 6174.2 & 93.8 & 6587.0 \\
& 90 & 89.6 & 6006.8 & 93.8 & 6037.1 & 85.0 & 6570.5 \\
220 & 30 & 94.4 & 6001.0 & 91.4 & 5902.8 & 95.1 & 6333.1 \\
& 60 & 91.5 & 5894.5 & 89.6 & 5853.1 & 85.1 & 6220.4 \\
& 90 & 87.8 & 5736.4 & 87.9 & 5745.1 & 78.9 & 6209.9 \\
\hline
\end{tabular}

Table 8. Chemical Compositions of Heartwood

\begin{tabular}{cccccc}
\hline Treatment & Extractives (\%) & Lignin (\%) & Holocellulose (\%) & Hemicellulose (\%) & Cellulose (\%) \\
\hline Control, 0 min & 13.9 & 22.3 & 75.5 & 24.7 & 50.8 \\
$180^{\circ} \mathrm{C}, 30 \mathrm{~min}$ & 12.9 & 24.3 & 73.5 & 24.0 & 49.5 \\
$180^{\circ} \mathrm{C}, 60 \mathrm{~min}$ & 11.3 & 24.8 & 71.9 & 23.1 & 48.8 \\
$180^{\circ} \mathrm{C}, 90 \mathrm{~min}$ & 8.8 & 25.5 & 68.9 & 21.2 & 47.7 \\
$200^{\circ} \mathrm{C}, 30 \mathrm{~min}$ & 10.3 & 24.6 & 67.6 & 20.3 & 47.4 \\
$200^{\circ} \mathrm{C}, 60 \mathrm{~min}$ & 8.4 & 25.2 & 66.4 & 19.5 & 46.9 \\
$200^{\circ} \mathrm{C}, 90 \mathrm{~min}$ & 5.3 & 26.4 & 64.7 & 18.9 & 45.8 \\
$220^{\circ} \mathrm{C}, 30 \mathrm{~min}$ & 8.8 & 25.5 & 64.5 & 19.2 & 45.3 \\
$220^{\circ} \mathrm{C}, 60 \mathrm{~min}$ & 5.5 & 26.2 & 62.1 & 18.3 & 43.8 \\
$220^{\circ} \mathrm{C}, 90 \mathrm{~min}$ & 2.0 & 27.3 & 61.1 & 17.9 & 43.2 \\
\hline
\end{tabular}

Table 9. Chemical Compositions of Sapwood

\begin{tabular}{cccccc}
\hline Treatment & Extractives (\%) & Lignin (\%) & Holocellulose (\%) & Hemicellulose (\%) & Cellulose (\%) \\
\hline Control, 0 min & 9.1 & 20.1 & 72.2 & 22.4 & 49.8 \\
$180^{\circ} \mathrm{C}, 30 \mathrm{~min}$ & 7.4 & 22.6 & 70.2 & 21.9 & 48.3 \\
$180^{\circ} \mathrm{C}, 60 \mathrm{~min}$ & 6.8 & 23.1 & 69.6 & 21.5 & 48.1 \\
$180^{\circ} \mathrm{C}, 90 \mathrm{~min}$ & 6.6 & 24.4 & 68.7 & 20.8 & 47.9 \\
$200^{\circ} \mathrm{C}, 30 \mathrm{~min}$ & 5.3 & 23.2 & 66.3 & 19.6 & 46.7 \\
$200^{\circ} \mathrm{C}, 60 \mathrm{~min}$ & 3.0 & 24.1 & 64.6 & 18.7 & 46.0 \\
$200^{\circ} \mathrm{C}, 90 \mathrm{~min}$ & 2.8 & 24.2 & 64.1 & 18.4 & 45.7 \\
$220^{\circ} \mathrm{C}, 30 \mathrm{~min}$ & 2.8 & 25.1 & 62.1 & 17.8 & 44.3 \\
$220^{\circ} \mathrm{C}, 60 \mathrm{~min}$ & 2.2 & 25.7 & 60.9 & 17.4 & 43.5 \\
$220^{\circ} \mathrm{C}, 90 \mathrm{~min}$ & 1.7 & 26.5 & 60.0 & 17.1 & 42.9 \\
\hline
\end{tabular}

Table 10. Correlation between colour, chemical composition and strength of 18 years-old Acacia mangium

\begin{tabular}{ccccccccccc}
\hline & $\Delta \mathrm{L}^{*}$ & $\Delta \mathrm{C}$ & $\Delta \mathrm{E}$ & Extractives & Lignin & Holo-cellulosi & Cellulose & Hemi-cellulose & MOR & MOE \\
\hline$\Delta \mathrm{L}^{*}$ & 1.000 & $0.774^{* *}$ & $-0.961^{* *}$ & $0.852^{* *}$ & $-0.244^{\text {ns }}$ & $0.730^{* *}$ & $0.692^{* *}$ & $0.737^{* *}$ & $0.704^{* *}$ & $0.125^{\text {ns }}$ \\
$\Delta \mathrm{C}$ & & 1.000 & $-0.901^{* *}$ & $0.918^{* *}$ & $-0.508^{*}$ & $0.910^{* *}$ & $0.880^{* *}$ & $0.907^{* *}$ & $0.818^{* *}$ & $0.515^{* *}$ \\
$\Delta \mathrm{E}$ & & & 1.000 & $-0.895^{* *}$ & $0.371^{\text {ns }}$ & $-0.817^{* *}$ & $0.794^{* *}$ & $0.838^{* *}$ & $0.688^{* *}$ & $0.607^{* *}$ \\
Extractives & & & & 1.000 & $-0.315^{\text {ns }}$ & $0.853^{* *}$ & $0.809^{* *}$ & $0.865^{* *}$ & $0.739^{* *}$ & $0.656^{* *}$ \\
Lignin & & & & 1.000 & $-0.630^{* *}$ & $-0.692^{* *}$ & $-0.547^{*}$ & $-0.802^{* *}$ & $-0.790^{* *}$ \\
Holocellulose & & & & & 1.000 & $-0.984^{* *}$ & $-0.984^{* *}$ & $0.930^{* *}$ & $0.919^{* *}$ \\
Cellulose & & & & & & 1.000 & $0.937^{* *}$ & $0.921^{* *}$ & $0.925^{* *}$ \\
Hemicellulose & & & & & & & 1.000 & $0.907^{* *}$ & $0.885^{* *}$ \\
MOR & & & & & & & & & 1.000 & $0.561^{* *}$ \\
MOE & & & & & & & & & & \\
\hline
\end{tabular}

ns $=$ not significant,$*=$ significant at $\mathrm{p} \leq 0.05, * *=$ significant at $\mathrm{p} \leq 0.01, \Delta \mathrm{C}=$ chroma changes,

$\Delta \mathrm{L}^{*}=$ changes in lightness, $\Delta \mathrm{E}=$ total colour differences. 


\section{Modulus of Elasticity}

The average MOE of oil-heat treated A. mangium was $6992.4 \mathrm{~N} / \mathrm{mm}^{2}$. The strength of the wood, however, varied between the wood portion heights. Table 7 shows the MOR and MOE of oil-heat treated A. mangium wood. MOE of treated wood decreased with extended duration. However, in each sampling height, there are only slight differences between increased in the duration of treatment which is not more than $3 \%$ strength loss. Thus, the duration is not significantly caused a reduction in MOE of treated wood. In each sampling height, increased in temperature from $180^{\circ} \mathrm{C}$ to $200^{\circ} \mathrm{C}$ almost tripled the MOE loss. However, the rate of loss in MOE slightly slowed when wood is treated at $220^{\circ} \mathrm{C}$. Therefore, temperature significantly affected the oil-heat treated wood.

The oil-heat treatment had caused MOE to decrease because MOE starts to decrease when the temperature is over $100^{\circ} \mathrm{C}$ (Bekhta \& Niemz, 2003). However, the reduction in MOE was varied with the only slight reduction that depending on species and treatment schedule (Korkut \& Hiziroglu, 2009).

In bottom and middle part of the tree, there was considerably decreased in MOE at different temperature and duration, but for the top part, the decreased in MOE were almost the same throughout the duration and temperature of treatment. For all parts, the highest reduction in MOE occurred at $220^{\circ} \mathrm{C}$ for 90 minutes where the percent losses were $16.6 \%, 17.8 \%$ and $12.7 \%$ for the bottom, middle and top. Sampling height is significantly affected the value of MOE (Table 10). The reduction in MOE of heat treated wood is consistent with research carried out by Tankut et al., (2014) which state that loss of MOE in heat treated wood is between 19\% and Estevez et al. (2009) and Sahin Kol (2010) suggest that the reduction in MOE can be around 1 to $72 \%$.

Similar to the MOR, reduction in MOE caused by the thermal degradation results in loss of chemical substances after oil-heat treatment where it is due in large part to de-polymerization reaction of wood polymers especially hemicellulose. Hemicellulose is important for wood strength but at high temperature, it can degraded due to its lower molecular weight thus it reduces the wood strength (Rowell, 2005). Other chemical components also degrade but it takes place at a higher temperature than hemicellulose, and they are responsible for the loss of wood strength.

\section{c. Chemical Compositions}

There exists a relation between oil-heat treatment and chemical composition of $A$. mangium where the chemical compositions either degrade or improved during the treatment process (Tables $8,9 \& 10$ ). Klason lignin improved in composition during treatment while the extractives, hemicelluloses, holocellulose and $\alpha$-cellulose degrade. The change in chemical composition able to explain the change in colour and mechanical properties of oil-heat treated wood.

\section{Holocellulose}

The holocellulose content in the heartwood of A. mangium control samples were $75.5 \%$ and sapwood $72.2 \%$. The oil-heat treatment caused a reduction in the holocellulose composition in the heartwood. The highest decreases in holocellulose content occurred when the wood was treated at $220^{\circ} \mathrm{C}$ for 90 minutes. with $61.1 \%$ of holocellulose remained while the lowest decreases occurred when the wood was treated at $180^{\circ} \mathrm{C}$ for $30 \mathrm{~min}$. with $73.5 \%$ of the holocellulose remained.

Extending the treatment duration further, decreases the holocellulose content. At $180^{\circ} \mathrm{C}$, every increment in duration doubled the loss in holocellulose content. Treatments at $200^{\circ} \mathrm{C}$ and $220^{\circ} \mathrm{C}$ with increment in duration decreases the holocellulose content steadily. However, the treatment duration does not significantly affect the holocellulose content (Table 10).

The holocellulose contents decreases with increases in temperature (Kacik et al., 2015). When the temperature of treatment reaches $180^{\circ} \mathrm{C}$, the holocellulose experiences loses of $8.7 \%$, at $200^{\circ} \mathrm{C} 14.7 \%$ and $220 \% 19.1 \%$. The significant changes in holocellulose content after $200^{\circ} \mathrm{C}$ also reported by Tumen et al., 2010 . The lowest decreased in holocellulose occurred at $180^{\circ} \mathrm{C}$ for 30 minutes which was $2.8 \%$ and highest at $220^{\circ} \mathrm{C}$ for 90 minutes which has degradation of $16.9 \%$. The loss of holocellulose increases with increases in treatment duration. However, only slight decreases in holocellulose content occurred at extended treatment duration. The highest difference in holocellulose loss was only $2.3 \%$.

An increase in temperature degrades holocellulose. However, the degradation rate of holocellulose in sapwood is slower than heartwood. At $180^{\circ} \mathrm{C}$, the highest loss in holocellulose is $8.2 \%$, at $200^{\circ} \mathrm{C}$ is $11.2 \%$ and at $220 \%$ is $16.9 \%$. The slower rate of holocellulose degradation may relate to the ability of holocellulose to degrade at a lower temperature as low as $100^{\circ} \mathrm{C}$ (Razak et al., 2011; Hill, 2006). The oil-heat treatment causes a decrease in holocellulose content significantly as was reported by Kacik et al. (2015). 


\section{The $\alpha$-Cellulose}

The control heartwood has $\alpha$-cellulose content of 50.8\%. The cellulose content in Acacia mangium ranged $34 \%$ to 47.2\% (Mohammed et al., 2011). Untreated Acacia mangium possess higher $\alpha$-cellulose content than treated samples because thermal treatment causes cellulose to degrade due to the split of high-molecular-weight fractions (Kacik et al., 2015). The $\alpha$-cellulose decreased with treatment durations and temperatures. The highest decreases occurred at $220^{\circ} \mathrm{C}$ for $90 \mathrm{~min}$. duration with $15 \%$ of $\alpha$-cellulose degraded and the lowest degradation took place at $180^{\circ} \mathrm{C}$ for 30 minutes.

At $180^{\circ} \mathrm{C}$ and $200^{\circ} \mathrm{C}$, the decreases in $\alpha$-cellulose at 30 and 60 minutes are almost the same and significant reduction in $\alpha$-cellulose occurs at 90 minutes. While, at $220^{\circ} \mathrm{C}$, decreases in $\alpha$-cellulose occurs almost at a steady rate where $\alpha$-cellulose degrade for $10.8 \%, 13.8 \%$ and $15.9 \%$ for 30,60 and 90 minutes, respectively. Decreases in $\alpha$-cellulose in a given duration was also observed by Gawron et al. (2011) in research on beech wood.

Reduction in $\alpha$-cellulose content was also affected by the increases in treatment temperature. Wood treated at $180^{\circ} \mathrm{C}$ possess lowest $\alpha$-cellulose contents due to the losses in cellulose at $200^{\circ} \mathrm{C}$ which were more rapid and double the cellulose degradation at $180^{\circ} \mathrm{C}$. Tumen et al. (2010) also reported the similar observation from their research. This is due to the reduction in the degree of polymerization (DP) of cellulose which started at $150^{\circ} \mathrm{C}$ (Cademartori et al., 2013). At $200^{\circ} \mathrm{C}$ the formation of volatile products such as levoglucosan, anhydroglucose, furan and furan derivatives occurred (Yildiz et al., 2006). In this study, the controlled wood contains $49.8 \%$ of $\alpha$-cellulose. The oil-heat treatment causes the $\alpha$-cellulose to degrade up to $13.9 \%$ until only $42.9 \%$ of cellulose remained in $220^{\circ} \mathrm{C}$ for 90 minutes treatment.

The losses of $\alpha$-cellulose were related to treatment duration. There were slight differences in the percentage of $\alpha$-cellulose between three (3) different treatment durations with the highest differences in $2.8 \%$ reduction. Reductions in $\alpha$-cellulose were also affected by the temperature. Like heartwood, a significant decrease in $\alpha$-cellulose occurs when the temperature of treatment was at $200^{\circ} \mathrm{C}$. The losses of $\alpha$-cellulose which was related to the degradation of the less orderly area in crystalline cellulose and degradation of the amorphous area in cellulose when the temperature was up to $200^{\circ} \mathrm{C}$ (Fengel \& Wegener, 1989). The cellulose degradation is only slightly affected by thermal treatment due to the high stability of cellulose and its high molecular weight (Candelier et al., 2013; Razak et al., 2011; Estevez \& Pereira, 2009). Cellulose degrades at a higher temperature than hemicelluloses, pectins, and starch (Razak et al., 2011). This proven by the highest percentage of $\alpha$-cellulose degradation at $15 \%$ while the highest hemicelluloses lose at $27.5 \%$.

\section{Hemicellulose}

The control wood of $A$. mangium heartwood contains about $24.7 \%$ of hemicelluloses. The degradation of hemicelluloses occurred with increasing duration of treatment. However, only slight decreases occurred for an extending of treatment duration and the highest decreases recorded at only $1.9 \%$ of holocellulose difference (Gawron et al., 2011). The hemicellulose contents were also affected by the increases in temperature during treatment. Hemicellulose started to degrade at $180^{\circ} \mathrm{C}$ was gave significant changes (Razak et al., 2012). Degradation of hemicellulose is due to the formation of formic and acetic acid that formed mainly from O-acetyl-galacto-gluco-mannan under the influence of temperature (Gawron et al., 2011).

In sapwood of oil treated A. mangium, the untreated samples contain $22.4 \%$ of hemicelluloses. The oil-heat treatment had affected the hemicelluloses to degrade, and the highest degradation of hemicelluloses occur at $220^{\circ} \mathrm{C}$ at 30 minutes where only $17.1 \%$ of hemicelluloses remained after the loss about $23.7 \%$ of hemicelluloses content.

The increase in duration caused decreased in hemicellulose content. However, there were only slight decreased in hemicelluloses content with increasing duration. For $180^{\circ} \mathrm{C}$ and $200^{\circ} \mathrm{C}$, the significant decrease in hemicellulose occurs at 60 minutes may due to the lower temperature of treatment thus need longer treatment duration for the decrease in hemicellulose. While at $220^{\circ} \mathrm{C}$, there are not many differences in loss of hemicellulose between each duration of treatment (Unsal et al., 2009). Treatment at $200^{\circ} \mathrm{C}$ significantly decreases the hemicellulose content where the decreases almost tripled compared at $180^{\circ} \mathrm{C}$. The decrease in hemicelluloses contents continued at $200^{\circ} \mathrm{C}$ and $220^{\circ} \mathrm{C}$.

\section{Klason Lignin}

The Klason lignin content in the heartwood of $A$. mangium is $22.3 \%$ whereas in sapwood is $20.1 \%$. The lignin content in wood is between 18 to $35 \%$ (Pettersen, 1984). However, a study by Mohammed et al., 2011 stated that lignin content in Acacia magnum is between 10.5 to $20.5 \%$. The oil-heat treatment had caused an increase in Klason lignin content. The low increment in Klason lignin content for heartwood occurred at $180^{\circ} \mathrm{C}$ for $30 \mathrm{~min}$. which were $9.0 \%$ and highest at $220^{\circ} \mathrm{C}$ for 90 minutes which are $22.4 \%$. The Klason lignin content increased with 
increased duration of oil-heat treatment. There is a slight increase in Klason lignin content for 30 and 60 minutes treatment duration. Considerable increase in Klason lignin content when the temp. Increases from $200^{\circ} \mathrm{C}$ to $220^{\circ} \mathrm{C}$. Similar observations were made by Yildiz et al., (2006) and Tumen et al., (2010) which supported this finding in their studies respective studies. There was a strong alteration in lignin structure occurred (Windeisen et al., 2009).

Polycondensation reactions occur during heating by increased cross-linking with separated substances from hemicellulose and cellulose that leads to stabilization or increase in lignin proportion (Gonzalez-Pena et al., 2009; Tumen et al., 2010; Cademartori et al., 2013); Herrera et al., 2014). However, lignin degradation also occurs during oil-heat treatment but resulting in the formation of a conjugated structure that contributes to the colour formation which eventually caused increased in lignin content (Chen et al., 2012). The Klason lignin content in sapwood is also increased with an increment of treatment temperature. Even though there is only a slight increased, the treatment temp. still becomes a major factor for lignin content increment rather than duration because high temperature of treatment helps to degrade wood materials and increase the Klason lignin content (Todara et al., 2013).

\section{Extractives}

Based on the experiment conducted, the heartwood of untreated A. mangium contains $13.9 \%$ of extractive while in the sapwood there were $9.1 \%$ of extractives. Normally, the extractive content in wood is around $20 \%$ (Pettersen, 1984).

The oil-heat treatment causes the decreases in extractive content. The lowest decreased is the wood treated at $180^{\circ} \mathrm{C}$ for 30 minutes which were $12.9 \%$ extractive remained after decreased for only $7.2 \%$. While wood treated at $220^{\circ} \mathrm{C}$ for 90 minutes has the highest decreased in extractives where only $2.0 \%$ extractive remained after decreased for $85.6 \%$. The percentage of extractive decreased with increased in the duration of treatment. Increased in duration at the same temperature almost doubled the loss in extractives. This can be observed from treatment at $180^{\circ} \mathrm{C}$ where percentage loss is $7.2 \%, 18.7 \%$, and $36.7 \%$ for 30,60 and $90 \mathrm{~min}$. respectively. While, for wood that treated at $200^{\circ} \mathrm{C}$ and $220^{\circ} \mathrm{C}$, the trend for percentage losses are varies.

The amount of extractive content decreases rapidly with the increases in temperature during oil-heat treatment. Considerable decreases in extractive content occurred the most when the temperature of treatment was between $180^{\circ} \mathrm{C}$ and $200^{\circ} \mathrm{C}$. The declined in the content were the highest at this point since at this temperature, the wood started to undergo chemical transformation after the loss of free and bound water (Estevez \& Pereira, 2009). Moreover, the temp. used in the treatment are enough to eliminate natural resins during term rectification process which caused the extractives to degrade (Brito et al., 2008).

Even though most original extractives disappear from wood with heat treatment, the extractive content increases significantly with the mass loss than decreased. The major increment was due to the water and ethanol extractives as a result of polysaccharide degradation (Estevez \& Pereira, 2009).

The lowest reduction in extractive was at $180^{\circ} \mathrm{C}$ for 30 minutes which $7.4 \%$ extractive remained after loss for about $18.7 \%$. The wood treated at $220^{\circ} \mathrm{C}$ for 90 minutes have the highest reduction in extractives where only $1.7 \%$ remained after reduction of $81.3 \%$.

Extractives of wood mostly disappeared or degrade during the thermal treatment especially volatile substances. However, new compounds can also be extracted from wood that resulted from degradation of cell wall structural components. These compounds are waxes, carbohydrates, tannins, resins and small amounts of hemicelluloses. While substances like fats and waxes moves along the axial parenchyma cell to the surface of the wood and expected to disappear (Estevez \& Pereira, 2009).

The heartwood has higher extractive content than the sapwood. This is due to the nature of the wood where extractive mainly located in the dead part of the tree (Rowell, 2005). The treatment temperature influences extractive degradation significantly (Estevez \& Pereira, 2009). This is proven through correlation analysis where the temperature is significantly affecting the extractive whereas duration does not affect the extractive content (Table 10).

\section{Statistical Analysis}

Correlation analysis was used to study the relationship between the 18-year-old acacia wood properties with colour, chemical and mechanical changes in the oil heat treatment process (Table 10). Changes in lightness correlated with all wood properties except lignin and MOE. The chemical composition of wood was highly correlated with the lightness of wood especially hemicellulose where decreases in lightness primarily caused by degradation of hemicellulose particularly pentosans (Bekhta \& Niemz, 2003; Huang et al., 2012). Moya et al. (2012) and Feher et 
al., (2014) stated a relation between lightness and extractive content in wood. Todorovic et al., (2012) also suggest that MOR correlated with lightness in wood.

Unlike lightness, chroma changes correlated with all the wood properties. Lignin is related to the red colour in the wood (Aksoy et al., 2011; Feher et al., 2014). While, yellow related with the photochemistry of chemical composition in cell wall including cellulose and hemicellulose, and wherein lignin was caused by lignin parts with quinonoid and stilbene structure (Sundqvist, 2004; Feher et al., 2014). It also caused by the organometallic complex in extractive (Sundqvist, 2004). Besides that, greyish appearances in wood are caused by cellulose and hemicellulose (Forsman, 2008; Feher et al., 2014).

The total colour difference correlated with each wood properties except lignin. For this reason, the total colour difference can be an indicator of chemical contents especially holocellulose (Chen et al., 2012; Huang et al., 2012). Besides, Bekhta and Niemz, (2003) and Todorovic et al., (2012), also suggest that total colour differences related to the wood strength, especially MOR.

Holocellulose positively correlated with all wood properties. Degradation of holocellulose content are caused by hemicellulose and cellulose because they positively correlated (Razak et al., 2012). Cellulose also positively correlated with all wood properties especially in wood strength where the structure of cellulose which are long, parallel, straight molecules that packed together are necessary to the wood strength (Poncsak et al., 2006). Therefore, break-up in cellulose structure lowers the MOR of wood.

Hemicellulose also correlates with all wood properties. In the heat treatment, the colour of the wood modified due to the released of by products from hemicellulose degradation (Tuong \& Li, 2010). Plus, the decline in the amount of hemicellulose caused decreased in lightness (Feher et al., 2014). Besides, loss in hemicellulose cause increase in the degree of polymerization in wood thus related to the degradation or rearrangement of amorphous cellulose (Cao et al., 2012). In mechanical properties, it plays an important role especially glucomannan where degradation of hemicellulose caused mass loss hence reduce the wood strength particularly MOR (Sahin, 2010; Borrega, 2011; Balkis et al., 2012; Kacikova et al., 2013).

Lignin correlated with all wood properties except lightness, total colour differences, and extractive content. Even though lignin only related with chroma colour, degradation of lignin would cause colour change (Li et al., 2011). Lignin also correlates with hemicellulose and cellulose content wherein heat treatment degradation of hemicellulose and cellulose increase the lignin content (Cademartori et al., 2013).

Extractive content positively correlated with all wood properties except lignin. The colour of treated wood is primarily determined by extractive content where extractive is the first chemical transformation occur in treated wood even at a low temperature (Feher et al., 2014; Nemeth et al., 2013).

MOR of the wood positively correlated with all wood properties, but MOE positively correlated with all wood properties except lightness. The colour of the wood has a strong correlation with wood strength (Bekhta \& Niemz, 2003). While, in heat treatment, depolymerization of cellulose and hemicellulose caused the wood to turns brittle and lowered the mechanical strength of the wood depending on treatment level (Gunduz et al., 2009).

\section{Conclusions}

The oil heat treatment process enhanced the colour of sapwood to match the heartwood of 18-year old Acacia mangium. The MOR and MOE of A. mangium wood decreased after treatment. The MOR and MOE decreases with increases in temperature. Durations of treatment affected the MOR values. Acacia wood treated at $200^{\circ} \mathrm{C}$ and $220^{\circ} \mathrm{C}$ for the duration of 60 and 90 minutes showed considerable changes in the chemical composition. Holocellulose, hemicellulose, $\alpha$-cellulose, extractive degraded and the Klason lignin increases in contents after the oil-heat treatment process. The oil heat treatment process at $200^{\circ} \mathrm{C}$ for 60 minutes is recommended for acacia mangium wood as it improved the colour of A. mangium and standardized the colour of sapwood and heartwood. The loss in strength at this temperature and duration is acceptable as the treated wood only loss up to $15 \%$ strength in MOR and $10.7 \%$ in MOE.

\section{References}

Aksoy, A., Dereci, M., Baysal, E., \& Toker, H. (2011). Colour and gloss changes of Scots pine after heat modification. Wood Research, 56(3), 329-336

Aydemir, D., Gunduz, G., \& Ozden, S. (2010). The influence of thermal treatment on colour response of wood materials. Colour Research and Application, 37(2), 148-153.

Balkis Fatomer, A. B., Hiziroglu, S., \& Md Tahir, P. (2012). Properties of some thermally modified wood species. Materials and Design, 43, 348-355. 
Bekhta, P., \& Niemz, P. (2003). Effect of high temperature on the change in colour, dimensional stability and mechanical properties of spruce wood. Holzforschung, 57, 539-546.

Borrega, M. (2011). Mechanisms affecting the structure and properties of heat-treated and high temperature dried Norway Spruce (Picea Abies) wood. Dissertation. University of Eastern Finland.

Brito, J. O., Silva, F. G., Leao, M. M., \& Almeida, G. (2008). Chemical composition change in eucalyptus and pinus woods submitted to heat treatment. Bioreources Technology, 99, 8545-8548.

BS EN 310: 1993. (1993). Wood Based Panels EN 310. Determination of modulus of elasticity in bending and of bending strength. British Standards Institution.

Cademartori, P. H. G., dos Santos, P. S. B., Seromo, L., Labidi, J., \& Gatto, D.A. (2013). Effect of thermal treatment on physicochemical properties of Gympie messmate wood. Industrial Crop and Protection, 45, 360-366.

Candelier, K., Dumarcay, S., Petrissans, A., Desharnais, L., Gerardin, P., \& Petrissans, M. (2013). Comparisons of chemical composition and decay durability of heat treated wood cured under different inert atmosphere: Nitrogen and vacuum. Polymer Degradation and Stability, 98, 677-681.

Cao, Y., Jiang, J., Lu, J., Huang, R., \& Wu, Y. (2012). The colour change of Chinese fir through steam heat treatment. BioResources, 7(1), 1123-1133.

Chen, Y., Gao, J., Fan, Y., \& Stark, N.M. (2012). The effect of heat treatment on the chemical and colour change of black locust (Robinia pseudoacacia) wood flour. BioResources, 7(1), 1157-1170.

Estevez, B. M., \& Pereira, H. M. (2009). Wood modification by heat: A review. BioResources, 4(1), 370-404.

Feher, S., Koman, S., Borcsok, Z., \& Taschner, R. (2014). Modification of hardwood veneers by heat treatment for enhanced colours. BioResources, 9(2), 3456-3465.

Fengel, D., \& Wegener, G. (1989). Wood Chemistry, Ultrastructure, Reactions. Walter de Gruyter and Co. Berlin, New York.

Forsman, S. (2008). Heat-treated wood- The concept house development. MSc Thesis. Lulea the University of Technology.

Gonzalez-Pena, M. M., Curling, S. F., \& Hale, M. D. C. (2009). On the effect of heat on the chemical composition and dimensions of thermally-modified wood. Polymer Degradation and Stability, 94, 2184-2193.

Gawron, J., Grzeskiewicz, M., Zawadzki, J., Zielenkiewicz, T., \& Radomski, A. (2011). The influence of time and temperature of beech wood (Fagus sylvatica L.) heat treatment in superheated steam on the carbohydrates content. Wood Research, 56(2), 213-220.

Guller, B. (2012). Effects of heat treatment on density, dimensional stability, and colour of Pinus nigra wood. African Journal of Biotechnology, 11(9), 2204-2209.

Gunduz, G., Aydemir, D., \& Karakas, G. (2009). The effect of thermal treatment on the mechanical properties of wild pear (Pyrus elaeagnifolia Pall) wood and changes in physical properties. Materials and Design, 30, 4391-4395.

Herrera, R., Erdocia, X., Llano-Ponte, R., \& Labidi, J. (2014). Characterization of hydrothermally treated wood in relation to changes on its chemical composition and physical properties. Journals of Analytical and Applied Pyrolysis, 107, 256-266.

Hill, C. A. S. (2006). Wood Modification: Chemical, Thermal, and Other Processes. John Wiley \& Sons Limited, England.

Huang, X., Kocaefe, D., Kofaece, Y., Buluk, Y., \& Pichette, A. (2012). A spectrocolourimetric and chemical study on colour modification of heat treated wood during artificial weathering. Applied Structure Science, 258, 5360-5369.

Izyan, K., Razak, W., Othman, S., Aminuddin, M., Tamer, A. T., \& Roziela Hanim, A. (2010). Enhancing the colour appearance of cultivated 15-year-old Acacia hybrid through the oil-heat treatment process. International Journal of Biology, 2(2), 199-209.

Kacik, F., Smira, P., Kacikova, D., Vel'kova, V., Nasswettrova, A., \& Vacer, V. (2015). Chemical alterations of pine wood saccharides during heat sterilization. Carbohydrate Polymers, 117, 681-686. 
Kacikova, D., Kacik, F., Cabalova, I., \& Durkovic, J. (2013). Effects of thermal treatment on chemical, mechanical and colour traits in Norway spruce wood. Bioresources Technology, 144, 669-674.

Kesik, H. I., Korkut, S., Hiziroglu, S., \& Sevik, H. (2014). An evaluation of properties of four heat treated wood species. Industrial Crops and Products, 60, 60-65.

Korkut, S., \& Hiziroglu, S. (2009). Effect of heat treatment on mechanical properties of hazelnut wood (Corylus colurna L.). Materials and Design, 30, 1853-1858.

Kotilainen, R. (2000). Chemical changes in wood during heating at $150^{\circ} \mathrm{C}-260^{\circ} \mathrm{C}$. Ph.D. Thesis. Jyvaskyla University, Finland.

Kubojima, Y., Okano, T., \& Ohta, M. (2000). Bending strength and toughness of heat-treated wood. Journal of Wood Science, 46, 8-15.

Li, X., Cai, Z., Mou, Q., \& Liu, Y. (2011). Effects of heat treatment on some physical properties of douglas fir (Pseudotsuga menziesii) wood. Advanced Materials Research, 197-198, 90-95.

Mohammed Raphy, K. M., Anoop, E. V., Aruna, P., Sheena, V. V., \& Ajayghosh, V. (2011). Provenance variation in wood chemical properties of Acacia mangium willd. and Acacia auriculiformis cunn. grown in a wet, humid site in Thrissur district of Kerala, South India. Journal Indian Academy Wood Science, 8(2), 120-123.

Moya, R., \& Julio, C. A. (2012). Variation of wood colour parameters of Techtona grandis and its relationship with physical environmental factors. Annals of Forest Science, 69, 947-959.

Mononen, K., Alvila, L., \& Pakkanen, T. T. (2002). CIE L* a* b* measurements to determine the role of felling season, log storage and kiln drying on the colouration of silver birch wood. Scandinavian Journal of Forest Resources, 17, 179-191.

Nemeth, R., Ott, A., Takats, P., \& Bak, M. (2013). The effects of moisture content and drying temperature on the colour of two poplars and robinia wood. Bioresources, 8(2), 2074-2083.

Pettersen, R. C. (1984). The chemical composition of wood. The chemistry of solid wood, 57-126.

Poncsak, S., Kocaefe, D., Bouazara, M., \& Pichette A. (2006). Effect of high temperature treatment on the mechanical properties of birch (Betula papyrifera). Wood Science Technology, 40, 647-663.

Rapp, A.O., \& Sailer, M. (2001). Heat treatment of wood in Germany: State of Art. Hamburg: Nundesforshungsanstalt fur Forst-und Holzwirtschaft.

Razak, W., Izyan, K., Roziela Hanim, A., Othman, S., Aminuddin, A., \& Affendy, H. (2011). Effect of hot oil treatment on colour and chemical changes in 15-year-old Acacia hybrid. Journal of Tropical Forest Science, 23(1), $42-50$.

Razak, W., Izyan, K., Tamer, A. T., Aminuddin, M., Othman, S., \& Farah, W. A. (2012). Effectiveness of hot oil treatment on cultivated 15 yer-old Acacia hybrid against Coriolus versicolours, Gloephyllum trabeum and Pycnoporus sanguineus. ISSN: 0126-6039. Journal of Science Malaysiana, 41(2), (163-169).

Rowell, R. M. (ed.). (2005). Handbook of wood chemical and wood composites. Madison. CRC Press.

Sahin Kol, H. (2010). Characteristic of heat-treated Turkish pine and fir wood after Thermowood processing. Journal of Environmental Biology, 31(6), 1007-1011.

Sundqvist, B. (2004). Colour changes and acid formation in wood during heating. Ph.D. thesis. Lulea the University of Technology.

Tankut, N., Tankut, A. N., \& Zor, M. (2014). Mechanical properties of heat-treated wooden material utilized in the construction of outdoor sitting furniture. Turkish Journal of Agriculture and Forestry, 38, 148-158.

TAPPI (Technical Association of the Pulp and Paper Industry). (1997). TAPPI Standard T204 om-98. TAPPI, Atlanta.

TAPPI (Technical Association of the Pulp and Paper Industry). (1999). TAPPI Standard T203 cm-99. TAPPI, Atlanta.

TAPPI (Technical Association of the Pulp and Paper Industry). (2002). TAPPI Standard T222 cm-02. TAPPI, Atlanta.

Todaro, L., Dichicco, P., Moretti, N., \& D'Auria, M. (2013). Effect of combined steam and heat treatments on extractives and lignin sapwood and heartwood of Turkey oat (Quercus cerris L.) wood. BioResources, 8(2), 1718-1730. 
Todorovic, N., Popovic, Z., Milic G., \& Popadic, R. (2012). Estimation of heat-treated beechwood properties by a colour change. BioResources, 7(1). 799-815.

Tumen, I., Aydemir, D., Gunduz, G., Uner, B., \& Cetin, H. (2010). Changes in the chemical structure of thermally treated wood. Bioresources, 5(3). 1936-1944.

Tuong, V. M. \& Li, J. (2010). Effect of heat treatment on the change in colour and dimensional stability of Acacia hybrid wood. BioResources, 5(2), 1257-1267.

Unsal, O., Buyuksari, U., Ayrilmis, N., \& Korkut, S. (2009). Properties of wood and wood-based materials subjected to thermal treatments under various conditions. International Conference "Wood Science and Engineering in the Third Millenium".

Windeisen, E., Bachle, H., Zimmer, B., \& Wegener, G. (2009). Relations between chemical changes and mechanical properties of thermally treated wood. Holzforschung, 63, 773-778.

Yildiz, S., Gezer E. D., \& Yildiz, U. C. (2006). Mechanical and chemical behavior of spruce wood modified by heat. Building and Environment, 41, 1762-1766.

\section{Copyrights}

Copyright for this article is retained by the author(s), with first publication rights granted to the journal.

This is an open-access article distributed under the terms and conditions of the Creative Commons Attribution license (http://creativecommons.org/licenses/by/4.0/). 